\title{
PUBLIC CAPITAL AND TOTAL FACTOR PRODUCTIVITY. NEW EVIDENCE FROM THE ITALIAN REGIONS, 1970-1998
}

\author{
Sergio Destefanis \\ CELPE \\ Università di Salerno \\ Italy \\ Vania Sena* \\ Aston Business School \\ Aston University \\ UK
}

Monday, 21 February 2005

\begin{abstract}
This paper analyses the relationship between industrial total factor productivity and public capital across the 20 Italian administrative regions. We add upon the existing literature in a number of ways: we analyse a longer period (1970-98); we allow for the role of human capital accumulation; we test for the existence of a long-run relationship between total factor productivity and public capital (through the panel techniques suggested in Im et al., 2001; Pedroni, 1997, 1999) and for weak exogeneity of public capital (Urbain, 1992); we assess the significance of public capital within a non-parametric set-up based on the Free Disposal Hull. The results confirm that public capital has a significant impact on the evolution of total factor productivity, particularly in the Southern regions. This impact is to be mainly ascribed to the core infrastructures (road and airports, harbours, railroads, water and electricity, telecommunications). Also, core infrastructures are found to be weakly exogenous.
\end{abstract}

Keywords: total factor productivity, public capital accumulation, long-run relationship, non-parametric frontiers.

JEL Classification: O40, R11, R53

\footnotetext{
* Corresponding author. Address for correspondence: Aston Business School, Aston University, Aston Triangle, Birmingham B4 7EF, UK. E-mail: v.sena@aston.ac.uk. We thank two anonymous referees for useful comments, Raffaele Paci and Lucio Picci for kindly providing us with their data, Peter Pedroni for providing us with the RATS code to perform panel cointegration tests, Speranza Nunziata for skilful research assistance. Previous drafts of this paper have been presented at the CEPR Conference on Dynamic Aspects of Public Expenditure, Copenhaghen, 28-30 September 2001, and at the Istituto di Studi Economici, Università Parthenope, Naples, 21 February 2002. We thank all participants and in particular Toke Aidt, Lars Bovenberg, Fabio Canova, Riccardo Marselli, Yongcheol Shin, Amedeo Spadaro and Salvatore Vinci for useful comments.
} 


\section{Introduction}

Italy is characterised by marked regional heterogeneity. As is well known, the Southern regions $^{\mathrm{i}}$ of Italy (Mezzogiorno for short) have consistently lagged behind the rest of the country in terms of per capita income and economic performance (Allen and Stevenson, 1974; Putnam, 1993; Paci and Saba, 1998). What are the factors which can explain the poor performance of these regions? A consensus has emerged among economists that a crucial characteristic of the Mezzogiorno economy is its sluggish supply side and ultimately its incapability to reach levels of total factor productivity (TFP henceforth) close to those of the Northern regions (for surveys of the relevant literature see Faini et al., 1993; Aiello and Scoppa, 2000; D’Acunto et al., 2004). For instance TFP in Italian industry grew on average at a rate of about $1.5 \%$ per annum from 1970 to 1998, but its level remained consistently lower in the Southern regions. The percentage gap between industrial TFP in the Mezzogiorno and in the rest of Italy was 23\% in 1970, 22\% in 1984 and 25\% in 1998, showing no sign of a catching-up process. In recent years, considerable scientific interest has arisen about the role that public capital can play in raising TFP. Several authors (Picci, 1999; Acconcia and Del Monte, 2000; Aiello and Scoppa, 2000; Bonaglia et al., 2000) have pointed out that public capital has a positive and significant impact on TFP in the Southern regions. These findings have obvious implications for the lively political debate about the role that public investment programmes can have in enhancing TFP in the private sector and in promoting the development of weaker areas. ${ }^{\text {ii }}$

From a methodological standpoint, this evidence is very much rooted in the seminal contribution of Aschauer (1989), who measured the impact of infrastructure on private output in the US by estimating an aggregate production function augmented by the stock of public capital. Various methodological objections have been raised about the validity of this estimation framework. First, in this approach, public capital is obviously assumed to be exogenous. However, feedback effects running from output and TFP to public capital may 
invalidate this assumption (Eisner, 1991; Tatom, 1991), which has seldom been tested in empirical work. Second, virtually all the empirical studies share the hypothesis of a CobbDouglas functional form for the production function. Imposing such a restrictive functional form may create biases in the parameter estimates. Third, attention has been drawn to the potential non-stationary nature of the data and the possible long-run relationships existing among the variables (Tatom, 1991; Munnell, 1992). The estimation procedure must take these features in due account. Fourth, it has been maintained that the significance of the infrastructure-productivity nexus can arise from unobserved heterogeneity among units in the regression. Indeed, it was observed that, once unobserved regional effects were allowed within US state panels, the elasticity of output to public capital was often no longer significant.

In this paper we provide some new estimates for the empirical relationship between public capital and industrial TFP across the 20 Italian administrative regions, analysing a longer time period (1970-98) and adopting a finer regional disaggregation than those considered in previous studies. Our ultimate goal is to assess the robustness of the evidence on the productivity of public capital (especially in the Mezzogiorno) from various standpoints. Therefore we test for the existence of a long-run relationship between total factor productivity and public capital (through panel techniques fully allowing for parameter heterogeneity across regions), and assess the weak exogeneity hypothesis for public capital adopting the procedure suggested in Urbain (1992). We provide nonparametric estimates of the infrastructure-productivity nexus, independent of any assumption on functional form. Also, we control for the role of human capital on growth, in view of the large regional differences in size and evolution of educational attainment.

The remainder of the paper is organised as follows. Section 2 presents a survey of the empirical literature on the relationship between public capital and TFP. Section 3 describes the empirical procedures and the data, while the results are shown and commented in 
Section 4. Section 5 concludes.

\section{Infrastructures and TFP: A Survey of the Existing Empirical Literature}

A number of empirical studies have attempted to quantify the relationship between public capital accumulation and productivity through the estimation of a production function augmented by the stock of public capital. The canonical examples of this approach are Aschauer (1989) and Munnell (1990). They estimate a Cobb-Douglas production function using national time series data for the US and other OECD countries covering the period from after Second World War to end of the 1980s. Both authors find large elasticities of output to public capital. These initial studies have been followed by a raft of papers, ${ }^{\text {iii }}$ mostly carried out on US data, both at national and regional (state) level.

Regional studies allow relaxation of the assumptions of uniform marginal factor productivity and technical progress within national boundaries. They are characterised more often than not by insignificant elasticities, while national level studies usually come up with significant public capital - growth relationships. For instance Evans and Karras (1994) and Holtz-Eakin (1994) find that the elasticity of output to public capital is not significant once unobserved regional effects are allowed within US state panels.

Two other early methodological issues pertain to the assumption of exogeneity for public capital and to the use of a restrictive functional form for the production function. In the first case, it has been argued that the established positive correlation between TFP and public capital could imply that TFP has a significant impact on public capital and not the other way round. Public capital would then behave as a normal good, whose demand increases when TFP and disposable income increase (Eisner, 1991; Tatom, 1991). The second issue relates to the frequent use of the Cobb-Douglas functional form, almost invariably with constant returns to scale, for the production function. It has been suggested that this restrictive set-up may be a source of upward bias in the estimating the output 
elasticity to infrastructure (Gramlich, 1994).

Another important methodological issue concerns the non-stationary nature of the data. Tatom (1991) first points out that, if public capital and the other variables are nonstationary, spurious statistical significance of the regression is likely to ensue. A first response to this problem was to first-difference the series (Evans and Karras, 1994; Garcia et al., 1996). However, estimation in first-differences removes all trend components, putting heavy weight on high-frequency disturbances: in a static specification, this is equivalent to assume that the impact on productivity of an increase in public capital in one year is fully realised during the same year (see Munnell, 1992). By contrast, economic theory suggests that TFP is affected by public capital at much lower frequencies. Indeed it is even suggested that the stock of public capital may have a permanent impact on productivity. More in detail, the following two channels are usually considered in the growth literature. First, public capital can raise the productivity of private capital so that the whole economy becomes more productive (Fisher and Turnovsky, 1998; Glomm and Ravikumar, 1998). This means that there is a stock of technical progress waiting "on the shelf” that can be incorporated in the production when new public investments take place (Canning et al., 1994). Second, investments in public capital may favour specialisation in sectors (or technologies) with higher productivity. For instance, transport infrastructures, by improving communications and by increasing the size of the market, allow firms to have access to high-volume and high-tech production techniques and therefore have a positive and permanent impact on aggregate productivity (Chatterjee et al., 2003).

Therefore, in recent years, there has been considerable search for steady-state relationships between public capital and TFP. The evidence is quite mixed. Some studies report evidence in favour of the existence of such a relationship (Lau and Sin, 1997; Batina, 1998; Albala-Bertrand and Mamatzakis, 2001; Everaert and Heylen, 2001), while others do not find it (Pereira and Flores de Frutos, 1999; Pereira, 2000; Sturm et al., 1995; Sturm and 
De Haan, 1995). This lack of conclusive evidence is not surprising, given the well-known lack of power of unit root and cointegration tests in small samples. A possible solution to the problem of small sample size is to use some recently developed testing procedures which use both the time-series and the cross-section information content of the data (Im et al., 2003; Pedroni, 1997, 1999).

There is an additional point to be made on the steady-state relationship between public capital and TFP. Its existence may mean that it is public capital to be driven by TFP according to the arguments made in Eisner (1991) and Tatom (1991). The stock of public capital has a permanent impact on productivity if there is a steady-state relationship and public capital is a long-run forcing variable, in the parlance of Granger and Lin (1995). In this case there are significant long-run effects from public capital to TFP, but not the other way round. As will be shown in Section 3, in a VECM set-up it is easy to ascertain whether public capital is long-run forcing. Interestingly, the same procedure was suggested in Urbain (1992) as a weak exogeneity test more powerful than the customary Hausman test.

Some of the above evoked issues have also been treated within the Italian literature on the relationship between public capital accumulation and productivity. Two studies of particular methodological interest are Picci (1999) and Bonaglia et al. (2000). Picci (1999) adopts panel data techniques in order to overcome the misgivings aired in Evans and Karras (1994) and in Holtz-Eakin (1994) about the neglect of cross-section heterogeneity (in this case among Italian regions). Cobb-Douglas production functions relating regional GDP to labour, private capital and public capital are estimated for the 20 Italian regions using pooled OLS, fixed effects and random effects models over the period 1970-1995. Further evidence is provided with respect to two sub-periods (1970-1982 and 1983-1995) and four macro-regions (North-West, North-East, Centre and South). Unlike in most of the US literature, output elasticity to public capital is found positive and significant (0.36) for the whole country also allowing for unobserved regional (and time) effects. Estimated 
elasticities are generally higher for the second sub-period, for the Southern regions, and in correspondence of the "core" component of public capital (see below for the definition of this component.). Interestingly, Picci (1999) also provides some tests of the Cobb-Douglas assumption. A $2^{\text {nd }}$-order translog functional form does not yield a significantly better fit for the production function. However, public capital is markedly less significant in the translog set-up, suggesting that further testing of the sensitivity of results to the functional form assumption may be appropriate.

Bonaglia et al. (2000) evaluate the impact of public capital on regional industrial output through three different methodologies: an index-based growth accounting approach, a production function approach (similar to the one adopted in Picci, 1999) and a cost function approach. ${ }^{\text {iv }}$ Again, evidence is provided for all regions and years (1970-1994), and for different sub-periods and (four) macro-regions. The main findings leave some doubts on the robustness of the infrastructure-productivity nexus in industry: public capital seems to contribute positively to growth for all regions and periods only within the index-based growth accounting approach (the elasticity of TFP growth to public capital growth being estimated at 0.47 ). On the other hand, no pervasive significant role is found for public capital as an input in the production function and as a shift term in the cost function. When dealing with regionally disaggregated evidence, the results indicate that at least the Mezzogiorno (and the Centre) regions benefit from public capital provision as an input in the production function and as a shift term in the cost function. Bonaglia et al. (2000) also consider the possibility that their estimates may be affected by the endogeneity of public capital. They report results from Hausman tests and instrumental variable estimates according to which endogeneity of public capital is not a problem. However, Urbain (1992) convincingly argues that there may be serious power problems for the Hausman test in a time series set-up, and provides an alternative test. Hence the interest of adopting the latter procedure in testing the (weak) exogeneity assumption for public capital. 
These methodological considerations set an agenda for further empirical analysis on the relationships between public capital and TFP across the Italian regions, which will be spelled out in the next section.

\section{The Empirical Analysis: Methodology and Data}

Our empirical analysis is articulated into two stages. First, we test for the existence of a long-run relationship between public capital and TFP, fully allowing for regional parameter heterogenity (Im et al., 2001; Pedroni, 1997, 1999). We also assess whether public capital is long-run forcing (Granger and Lin, 1995), which corresponds to the weak exogeneity test proposed by Urbain (1992). In the second stage, we test the significance of public capital within a non-parametric set-up based on the Free Disposal Hull (FDH: see Deprins et al., 1984; Tulkens, 1993; Kerstens and Vanden Eeckaut, 1999). By carrying out a nonparametric analysis of the relationship between output and public capital, we gauge the robustness of the results from the econometric estimates in relationship to the assumptions about functional form and returns to scale in the production function.

In our empirical analysis we analyse a longer time period (1970-98) than those considered in previous studies. We concentrate on the industrial sector (mining and manufacturing; electricity, gas and water; construction). This choice is justified both by the strategic importance of this sector as an engine of regional growth in Italy and Europe (Paci et al., 2003) and by the doubts that the findings of Bonaglia et al. (2000) leave on the robustness of the public capital-TFP nexus in industry. The data on regional value added, labour units, and labour income ${ }^{\mathrm{v}}$ have been taken from ISTAT Regional Accounting. The data for the stock of private capital provided by Raffaele Paci and Nicola Pusceddu from CRENOS, University of Cagliari, for the 1970-1994 period, were extended until 1998 following the same procedure adopted in Paci and Pusceddu (2000) for the previous period. The data on the stock of public capital have been provided by Lucio Picci from University 
of Bologna, and are obtained applying a perpetual inventory procedure on investment in public infrastructures. ${ }^{\text {vi }}$ Following a common procedure in this literature, these series are originally disaggregated in various categories (telecommunications, road and airports, harbours, railroads, educational and public buildings, water and electricity, hospitals, others), allowing us to construct two stocks for core and non-core infrastructures, as well as of a total stock. Core infrastructures include road and airports, harbours, railroads, water and electricity, telecommunications, while non-core infrastructures include educational and other public buildings, hospitals, other infrastructures.

A further novelty of our empirical analysis is that we correct the labour input for the regional stock of human capital. The crucial relevance of human capital for growth has been highlighted in a host of contributions stemming from Lucas (1988) and Mankiw et al. (1992). Neglecting this variable is a potentially serious source of misspecification, especially if one considers the large differences in size and evolution of human capital endowments across Italian regions. ${ }^{\text {vii }}$ Following what is by now common practice in growth accounting, we adopted the technique suggested in Hall and Jones (1999) in order to augment labour for human capital. Let $\mathrm{L}_{\mathrm{it}}$ stand for the number of employees (in a given industry) in region $\mathrm{i}$ at time $\mathrm{t}, \mathrm{F}_{\mathrm{it}}$ and $\mathrm{M}_{\mathrm{it}}$ for the average number of years of education of, respectively, female and male employees (in a given industry) in region $\mathrm{i}$ at time t. The latter are taken from Destefanis et al. (2004), where details are provided about the procedure utilised to obtain these values. Then, labour augmented for human capital accumulation in region $\mathrm{i}$ at time $\mathrm{t}$ can be defined by:

(3.1) $\mathrm{N}_{\text {it }}=\mathrm{L}_{\mathrm{it}} \mathrm{H}_{\mathrm{it}}=\mathrm{L}_{\mathrm{it}} \mathrm{e}_{\mathrm{it}}{ }_{\phi_{\mathrm{F}}}^{\mathrm{F}}$ it $\left.+\phi_{\mathrm{M}}{ }^{\mathrm{M}}{ }_{\text {it }}\right]$

where $\phi_{\mathrm{F}}$ and $\phi_{\mathrm{M}}$, the coefficients on education in the Mincer earning functions estimated for Italy by Brunello et al. (1999), are respectively equal to 0.077 and 0.062 . viii 


\section{1) TFP and public capital. Panel estimates}

In the panel analysis, we assess the public capital-TFP nexus relying on a TFP measure computed through a Divisia-Tornqvist index: value added is the output and private capital and (human-capital augmented) labour are the inputs. In the computation of the DivisiaTornqvist indices we postulate constant returns to scale. Initial values are computed by assuming a constant-returns-to-scale Cobb-Douglas production function with constant coefficients throughout time and producers (at sample mean values). Since we adopt the assumption of constant returns to scale for the TFP index, we maintain it for the role of public capital in the panel analysis. Hence, the stock of public capital entering the panel regressions is divided by one of the private inputs (labour).

Why relying on input-share weighted indices instead of including public capital along with labour and private capital in a regression explaining value added? The main reason for this is that we want to adopt a very parsimonious specification on rather short time series and yet be able to analyse carefully the dynamic structure of the estimates, also taking into account the non-stationary features of our data. In particular we want to be able to ascertain the existence of a cointegrating relationship between infrastructures and TFP, and to test whether public capital is weakly exogenous. Both things seem difficult to achieve by estimating a fully-fledged production function, given our data constraints.

We adopt the following empirical approach. First we ascertain the existence of a cointegrating relationship between TFP and public capital, relying on some recently developed panel techniques (Pedroni, 1997, 1999; Im et al., 2001). The concern for the lack of power of unit root and cointegration tests in small samples has prompted the development of testing procedures that take into account both the time-series and the crosssectional nature of the data (see for instance the discussion in Cavanagh et al., 1995). As far as unit root testing is concerned, Im et al. (2001) provide a test (henceforward, the t-bar 
test) allowing each panel member to have a different intercept and time trend, as well as different autoregressive parameters and short-run dynamics, under the alternative hypothesis of trend stationarity. The test statistic is distributed as $N(0,1)$ under the null of a unit root: large negative values lead to rejection of the null in favour of stationarity.

If the series under examination turn out to be $I$ (1), we can test for the existence of cointegration vectors among them. We use for this purpose the ADF group-mean test developed in Pedroni (1997, 1999), which allows for heterogeneity both in cointegrating parameters and short-run dynamics across panel members. This procedure consists in estimating first the cointegrating regression:

(3.2) $a_{i t}=\alpha_{i}+\beta_{t}+\gamma_{i} x_{i t}+\varepsilon_{i t}$

which takes into account both regional and common time effects and allows the cointegrating relationship to vary across regions. We then test for stationarity along a constant mean of the error terms, using the ADF based group-mean panel cointegration test developed in Pedroni (1997, 1999), that is closely related to the t-bar test - in particular, it is distributed as a $N(0,1)$ under the null of a unit root.

Once ascertained the existence of cointegration, we test for weak exogeneity along the following lines. We include our estimates of the cointegrating relationship in the following VECM system:

$$
\Delta a_{i t}=\alpha_{1 i}+\alpha_{11}^{i} \Delta a_{i t-1}+\alpha_{12 i} \Delta x_{i t-1}+\alpha_{13 i} \hat{\varepsilon}_{i t-1}+e_{i t}
$$

$$
\Delta x_{i t}=\alpha_{2 i}+\alpha_{21 i} \Delta a_{i t-1}+\alpha_{22 i} \Delta x_{i t-1}+\alpha_{23 i} \hat{\varepsilon}_{i t-1}+e_{i t}
$$

where $a_{i t}$ is total factor productivity, $x_{i t}$ are (core, non-core, total) infrastructures, $\hat{\varepsilon}_{i t}$ is the 
residual from the cointegrating relationship, and $\mathrm{e}_{i t}$ is a random term. If the $\hat{\varepsilon}_{\text {it }}$ 's turn out to be significant only in (3.3), public capital is long-run forcing and, according to the test proposed in Urbain (1992), is weakly exogenous. The significance of $\hat{\varepsilon}_{\text {it }}$ in both (3.3) and (3.4) would imply that public capital is not weakly exogenous, meaning that inference about the impact of public capital on TFP cannot be efficiently made conditionally on public capital alone. On the other hand, if the $\hat{\varepsilon}_{\text {it }}$ 's show up as significant in (3.4) only, it would be TFP to be long-run forcing and weakly exogenous.

\section{2) TFP and public capital. Non-parametric estimates}

The specification of the public capital-TFP nexus in the panel analysis is based on a set of restrictive assumptions on the production technology, such as constant returns to scale and a given functional form. In view of this, it seems desirable to test the relevance of public capital in the production process also through a very different route. Relying on some recent developments of the non-parametric approach to the quantitative analysis of production (Deprins et al., 1984; Tulkens, 1993; Kerstens and Vanden Eeckaut, 1999; Banker, 1996), we ascertain whether public capital enters significantly in a production set including value added as output and labour and private capital as other inputs.

Non-parametric methods provide estimates of the upper boundary of a production set (the so-called production frontier) without supposing the existence of a functional relationship between inputs and outputs (Farrell, 1957). The frontier is supported by some of the observed producers, which are defined efficient. Not assuming a specific functional relationship between output and inputs is a big advantage when analysing the productive performance of different countries or regions. Therefore, non-parametric frontiers have also been used to carry out empirical research on cross-country or cross-region convergence. Notable contributions in this field include Kumar and Russell (2002), as well as Arcelus and Arocena (2000), Maudos et al. (2000), Henderson and Russell (2001). 
Non-parametric methods are divided between those that impose upon the production set the hypothesis of convexity (usually gathered under the label of Data Envelopment Analysis, or DEA) and those that do not need this assumption (the Free Disposal Hull FDH - approach proposed in Deprins, et al., 1984, Tulkens, 1993). In the latter case, the only property imposed on the production set is strong input and output disposability, while in DEA the additional hypothesis of convexity is made. More formally, in FDH, for a given set of producers $Y_{0}$, the reference set $Y\left(Y_{0}\right)$ is characterised, in terms of an observation i, by the following postulate:

(3.5) $\left(\mathbf{X}^{\mathrm{i}}, \mathbf{Y}^{\mathrm{i}}\right)$ observed, $\left(\mathbf{X}^{\mathrm{i}}+\mathbf{a}, \mathbf{Y}^{\mathrm{i}}-\mathbf{b}\right) \in Y\left(Y_{\mathrm{O}}\right), \mathbf{a}, \mathbf{b} \geq 0$

where $\mathbf{a}$ and $\mathbf{b}$ are vectors of free disposal of input and output, respectively. In other words, due to the possibility of strong input and output disposability, the reference set includes all the producers which are using the same or more inputs and which are producing the same or less output in relation to observation $i$.

Let us take as an example Fig. 3.1, where we consider a technology with one input (X) and one output (Y). The input-output pairs correspond to producers examined at a given point in time. Beginning with observation $\mathrm{B}$, we define every observation located at its right and/or below it (that is with more input and same output, or with less output and same input; or else with more input and less output, as F) as dominated by B. 
FIG. 3.1

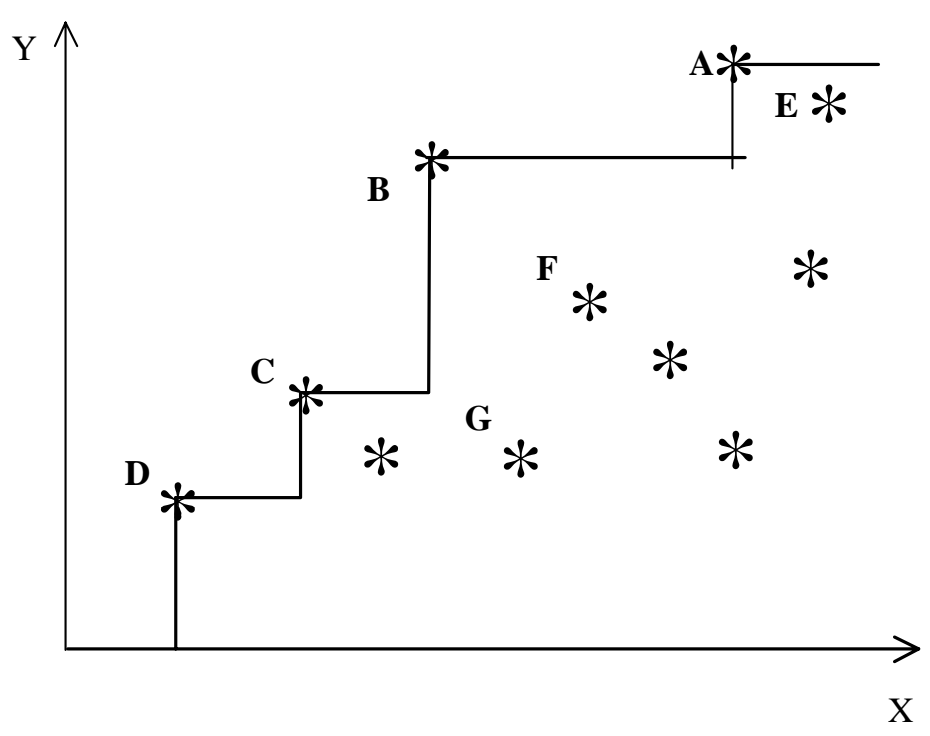

In the FDH approach, this comparison is carried out for every observation, and observations not dominated by any other observation are considered efficient producers, belonging to the frontier of the reference set: On the other hand, the observations that are dominated are considered inefficient. Non-parametric frontier techniques share the hypothesis that the distance of inefficient producers from the frontier must be entirely explained by a factor (or a set of factors) traditionally termed inefficiency, which obeys a one-sided statistical distribution. For our aims, it is fundamental to stress that, if some inputs are not duly included in the production set, inefficiency can also represent a relative lack in one of these inputs (for instance, public capital). Subsequently, frontier analysis can be used to detect not only the inability to use a technology optimally (that is, inefficiency proper), but also relative gaps in factor endowments. In our case, by comparing the mean efficiency scores obtained with and without public capital in the production set we ascertain its significance as an additional input.

The adoption of FDH allows us to leave behind the hypothesis of convexity of the production set typical of DEA. This means that the frontier obtained through FDH is likely to fit more closely the data than the one obtained through DEA, if the reference set is characterised (at least locally) by the existence of non-convexities. ${ }^{\mathrm{ix}}$ Also, as the frontier of 
the reference set is made up of actually existing units (rather than by a convex hull), FDH will be less sensitive to the presence in the reference set of outliers (or of erroneously measured values) than DEA. More precisely, the part of the frontier influenced by the presence of the outlier will be smaller with FDH than with DEA. One problem with FDH is that possibly many observations may be efficient because they are located in an area of the production set where there are no other observations with which they can be compared (efficiency by default). An undesirable consequence of this in the present context is that if mean efficiency rises subsequent to the inclusion of infrastructures in the production set, this could be ascribed to the appearance of a larger number of efficient-by-default observations (the larger input set reduces the scope for comparisons and increases the number of efficient-by-default observations). This problem is particularly relevant in small data-sets (like ours). To circumvent it, we use a refinement of the FDH, the FDH-VP (variable-parameter FDH) proposed by Kerstens and Vanden-Eeckaut (1999), which decisively reduces the problem of efficiency by default.

FDH-VP is defined as the intersection of FDH technologies that impose by assumption non-decreasing and non-increasing returns to scale. First, each observation is compared not only to any other observation but also to their smaller or larger proportional replicas; then, one selects for each given observation the assumption about returns to scale that yields the highest efficiency score. While FDH-VP differs in no way from traditional FDH in terms of the underlying hypotheses about the production set (strong input and output disposability, variable returns to scale), Briec et al. (2004) show that it is not the inner bound technology in a non-convex world (a property fulfilled by traditional FDH). Yet, FDH-VP greatly increases the scope for comparisons between observations, reducing correspondingly the problem of efficiency by default ${ }^{\mathrm{x}}$ and therefore curtails the risk that a higher mean efficiency in the presence of infrastructures may simply be the consequence of a larger number of efficient-by-default observations. 
Hence an output-oriented ${ }^{\mathrm{xi}}$ FDH-VP approach is used in this paper to ascertain the significance of public capital as an additional input in the production set. We first estimate a baseline specification with value added as output and labour and private capital as inputs. Obviously we always refer to the industrial sector and to human capital-augmented labour input. Then, we also include among the inputs the stock of core, non-core, total infrastructures. If infrastructures are a relevant input, the efficiency scores of the production set including their stocks should differ significantly from the baseline ones. This significance is assessed through two tests: a standard t-test and a Kolmogorov-Smirnov test (these tests are shown to have reasonable small-sample performance in Kittelsen, 1999). We refrain from using the bootstrapping test procedures suggested by Simar and Wilson (2000a; 2000b; 2001) because of their heavy computational burden.

\section{The Empirical Analysis: the Results}

\section{1) TFP and public capital. Panel estimates}

We begin the panel cointegration analysis by carrying out the t-bar test provided in Im et al. (2001). As suggested in Hall and Mairesse (2002), this test is carried out after removing from each variable the year-specific means. The results are shown in Table 4.1 for ADF regressions of $0^{\text {th }}, 1^{\text {st }}$ and $2^{\text {nd }}$ order. Core, non-core and total infrastructures can clearly be regarded as $I$ (1) series, while the evidence for TFP apparently indicates that this series is trend-stationary. However, as shown in Karlsson and Löthgren (2000), the rejection of the null can be driven by a few stationary series. In our case, large negative values for the Veneto and Friuli Venezia Giulia ADF statistics seem to be crucially important in dictating the overall results (the regional ADF values are not given here in order to save space and are available on request). Hence in what follows we regard also TFP as $I$ (1), and proceed to test the existence of cointegration vectors among TFP and various stocks of infrastructures. Should this hypothesis be inappropriate, we expect this to be unveiled by 
the cointegration tests and by the behaviour of the related VECM's (a similar argument has been made by Kremers et al., 1992, in time series analysis, and by Marrocu et al., 2000, in a panel set-up).

In Table 4.2 we report values for the long-run elasticities from the cointegration vectors. These elasticities are very often positive for core infrastructures, smaller in absolute value (and sometimes negative) for non-core infrastructures, positive again for total infrastructures. Also, the largest (positive) elasticities relate to the North-Eastern, SouthWestern and South-Eastern regions. Possibly, for North-Eastern regions this evidence is flawed inasmuch as TFP in these regions may be better described as a trend-stationary process. We then test for the existence of cointegration vectors using the ADF group-mean test developed in Pedroni $(1997,1999)$. The results of these tests are reported in Table 4.3. Again, we show statistics from ADF regressions of $0^{\text {th }}, 1^{\text {st }}$ and $2^{\text {nd }}$ order. Like for the t-bar test, large negative values lead to rejection of the null (in this case of no cointegration). The evidence in Table 4.3 leads to rejection of the null of no cointegration, particularly in the case of core infrastructures.

Finally, we ascertain whether public capital is long-run forcing. We test whether the residuals from the cointegrating relationships enter significantly in a VECM system analogous to (3.3)-(3.4). In Table 4.4 we provide the results obtained for a $1^{\text {st }}$ order VAR (very similar results are obtained for other lag lengths). The null of no long-run effects from infrastructures to TFP is always decisively rejected, but in the case of non-core infrastructures there is also some evidence against the other null (no long-run effects from TFP to infrastructures). This would imply that non-core infrastructures are not weakly exogenous, and that inference about the impact of non-core infrastructures on TFP cannot be efficiently made conditionally on them alone. On the other hand, it seems that the impact of total infrastructures on TFP is largely dictated by the relationship between core infrastructures and TFP: both core and total infrastructures are long-run forcing and hence 
weakly exogenous.

A final point about the VECM estimates: the good quality of their diagnostics (not reported here and available on request) vindicates both their reliability and the choice of regarding TFP as $I(1)$.

\section{2) TFP and public capital. Non-parametric estimates}

Some recent contributions (Kittelsen, 1999; Simar and Wilson, 2000a) have highlighted the possibility that non-parametric frontier methods may run into small-sample problems for sample sizes close or smaller than 100 observations. Accordingly, we apply FDH-VP not on single years but on four sub-samples roughly corresponding to cyclical phases of the Italian economy: 1970-75, 1976-81, 1982-90, 1991-98. The basic assumption behind this procedure is that the state of technology does not change appreciably within any one of these sub-samples.

The results, which are presented in Tables 4.5 and 4.6, point to the significance of public capital. Like in the panel analysis, however, this impact is to be mainly ascribed to core infrastructures and is generally stronger in the Mezzogiorno. In Table 4.5 these points are made in an informal manner: we present the regional means over the four periods for the FDH-VP efficiency scores. The difference between the mean scores obtained without and with infrastructures in the production set are clearly strongest for core infrastructures. Also, the largest differences are found for the North-Eastern, South-Western and South-Eastern regions. All this is remarkably close to the evidence that can be gathered from Table 4.2. Indeed, the area which gains most from core infrastructures is the South-East, with both the North-West and the South-West benefiting less. Table 4.6 provides similar, although more statistically based, evidence. Its perusal indicates that significance levels are noticeably lower in the case of core infrastructures (especially for the t-test, which is expected to be more powerful than the KS-test). 


\section{Conclusions}

This paper focused on the impact of public capital on TFP in Italian regions. We have therefore analysed the relationship between productivity and public capital stock, using data for the 20 Italian administrative regions over the a longer time period (1970-98) than those considered in previous studies. We have concentrated on the industrial sector, assessing the robustness of the public capital-TFP nexus from several standpoints. We considered explicitly the non-stationary nature of the data and tested for the existence of a cointegrating relationship between public capital and TFP through panel techniques that fully allow for parameter heterogeneity across regions. We tested the weak exogeneity of public capital through the procedure proposed in Urbain (1992). We assessed the significance of public capital within a non-parametric set-up based on a refinement of the Free Disposal Hull. Finally, we controlled for the role of human capital on growth, in view of the large regional differences in size and evolution of educational attainment.

We find a significant impact of public capital on industrial TFP. On average we obtain larger and more significant estimates for the elasticity of industrial value added to public capital than in Bonaglia et al. (2000), arguably because our panel procedures fully allow for the non-stationary nature of the data and for parameter heterogeneity across regions. Our elasticities (on average, 0.17 for core infrastructures and 0.12 for total infrastructures) are close to the 0.10 guess-estimate proposed in De la Fuente (2002). Still, we find a stronger impact of public capital in the Mezzogiorno than in the rest of Italy, and the core component of infrastructures comes out much more strongly.

In qualitative terms there is broad agreement between our findings and those from Bonaglia et al. (2000) - as well as from Picci (1999). The bulk of the Italian evidence points to a significant (albeit possibly small) impact of infrastructure on TFP, in contrast with often insignificant results obtained for the US state panels, but not with the findings of 
Mas et al. (1996) for a panel of Spanish regions. This evidence has obvious implications for the debate (to which we alluded in the Introduction) about the role of public investment programmes on regional growth. May be, public capital significantly contributes to output across Italian regions because infrastructure stocks have not yet reached an adequately high level, at which some sort of saturation effect may set in (for a similar argument about Spanish data see Mas et al., 1996; De la Fuente, 2002).

In any case, the finer regional disaggregation of our analysis and the results from our tests provide ground for further considerations. A sharp divide emerges in the Mezzogiorno between the South-West and the South-East, with the latter area benefiting more from public capital accumulation. This finding can be explained by differences in industrial structure and environment (D’Acunto et al., 2004, find that at least in Puglia manufacturing is more reactive to exogenous demand pressure) or by the greater effectiveness of public investment in the South-East (see for instance the evidence reported in Golden and Picci, 2004). Another important result is that some doubts arise on the weak exogeneity of noncore infrastructures. Possibly, non-core infrastructures behave like a normal good: demand for them depends (among other things) on size of the industrial sector. This would imply that inference about the impact of non-core infrastructures on TFP cannot be efficiently made conditionally on them alone. The bottom line seems to be that core infrastructures have a key role in promoting regional industrial development: investments in core infrastructures surely have a stronger impact on the TFP of an area; eventually, through higher TFP, they can also induce investments in non-core infrastructures with an additional impact on regional development.

More precise indications for policy-making can come from further research on these matters. ${ }^{\text {xii }}$ In particular, the evaluation of regional differences in the impact of infrastructure on productivity deserves more careful consideration. Explanations for the regional pattern of this impact could rely not only on the composition of expenditure (within core and non- 
core infrastructure), but also on differences in economic environment (for instance, D’Acunto et al., 2004, find significant regional differences in the impact of export demand on growth). A crucial field of analysis is, in this respect, the effectiveness of public investment programmes. As shown in Golden and Picci (2004), this effectiveness is strongly linked to the factors unearthed by Putnam's analysis of social capital (Putnam, 1993; Helliwell and Putnam, 1995). Interesting evidence in this ambit can also come from the study of the role of European Structural Funds in the programme selection and financing. 


\section{ENDNOTES}

${ }^{\mathrm{i}}$ These regions are Abruzzo, Molise, Campania, Puglia, Basilicata, Calabria, Sicilia and Sardegna. In order to clarify some evidence given below note that Campania, Calabria, Sicilia and Sardegna belong to the SouthWest. Abruzzo, Molise, Puglia and Basilicata belong to the South-East. Furthermore, the other region groupings are the North-West (Piemonte, Val d'Aosta, Lombardia, Liguria); the North-East (Trentino Alto Adige, Veneto, Friuli Venezia Giulia, Emilia Romagna); the Centre (Toscana, Umbria, Marche, Lazio).

ii See on this Ministero dell'Economia (2001), as well as Boldrin and Canova (2001) and the references there provided. See also Biehl (1986).

iii This literature is best summarised in Sturm (1998).

iv The cost function approach is exemplified by Lynde and Richmond (1992) and Morrison and Schwartz (1996). In this paper we concentrate on the production function approach, still by far the most widely adopted in the literature.

${ }^{\mathrm{v}}$ Educational attainment in Southern regions has been typically lower and growing at a faster rate than in the North (the average gap was 16 percentage points in 1970 and 7 percentage points in 1998).

${ }^{\mathrm{vi}}$ We also tried a second measure of human capital, where the Mincerian coefficients (always from Brunello et al., 1999) were 0.055 for Centre-Northern males, 0.068 for Southern males, 0.071 for Centre-Northern females, 0.083 for Southern females. Using this measure did not yield results appreciably different from those which we report below.

${ }^{\text {vii }}$ Labour income data have been constructed taking dependent labour income and adding to it an estimate of independent labour income (obtained assuming that independent labour income per worker is equal to dependent labour income per worker).

viii See for details Picci (1999); Bonaglia and Picci (2000).

${ }^{\text {ix }}$ It has been recently observed (Mundlak et al., 1999; Mundlak, 2000) that in cross-country (or cross-region) productivity comparisons one must rely on empirical aggregate production frontiers obtained from unobservable micro frontiers. In this case, when the available technology includes more than one technique, a modification of the environment faced by producers may lead to changes in technique (as well as to changes in the output-input mix for a given technique), and the hypothesis of convexity may not be respected for the observable aggregate production frontiers.

${ }^{x}$ Destefanis and Storti (2002) provide an example of this within an empirical analysis of cross-country technological catch-up.

${ }^{x i}$ We do not claim any hard theoretical ground for this choice. However, if we take an input orientation, in a two- or three input space the commonly adopted Debreu-Farrell measure of efficiency may not measure technical efficiency (in the sense of Koopmans, 1951) exhaustively. See on this Lovell (1993).

xii There are two issues of paramount importance for the evaluation of public investment programmes that are squarely beyond the scope of our analysis: the opportunity cost of the invested resources and the typically distortionary impact of the taxes financing the programmes. Bonaglia et al. (2000) provide some tentative evidence on the first issue. 


\section{REFERENCES}

Acconcia, A., Del Monte, A., (2000), Regional Development and Public Spending: The Case of Italy, Studi Economici, 55(72): 5-24;

Albala-Bertrand J.M., Mamatzakis E.C. (2001), Is Public Infrastructure Productive? Evidence from Chile, Applied Economics Letters, 8 (3), 195-198.

Aiello F., Scoppa V. (2000), Uneven Regional Development in Italy: Explaining Differences in Productivity Levels, Giornale degli Economisti, 59, 270-298.

Allen K., Stevenson A. (1974), An Introduction to the Italian Economy, London, Martin Robertson.

Arcelus F.J., Arocena P. (2000), Convergence and Productive Efficiency in Fourteen OECD Countries: A Non-Parametric Frontier Approach, International Journal of Production Economics, 66 (2), 105-117.

Aschauer D. (1989), Is public expenditure productive? Journal of Monetary Economics, 23, 177-200.

Banker R.D. (1993), Maximum likelihood, consistency and Data Envelopment Analysis: a statistical foundation, Management Science, 39, 10, 1265-1273.

Batina, R.G. (1998), On The Long-Run Effects of Public Capital and Disaggregated Public Capital on Aggregate Output, International Tax and Public Finance, 5 (3), 263-281.

Biehl D. (1986), The Contribution of Infrastructure to Regional Development. Final Report, Luxembourg, European Communities Commission.

Boldrin M., Canova F. (2001), Inequality and Convergence in Europe's Regions: Reconsidering European Regional Policies, Economic Policy, n. 32, 205-45.

Bonaglia F., La Ferrara E., Marcellino M. (2000), Public Capital and Economic Performance: Evidence from Italy, Giornale degli Economisti e Annali di Economia, 59, 221-244.

Bonaglia F., Picci, L. (2000), Lo stock di capitale nelle regioni italiane, Dipartimento di 
Scienze Economiche, Università di Bologna, WP n. 374.

Briec W., Kerstens K., Vanden Eeckaut P. (2004), Non-convex Technologies and Cost Functions: Definitions, Duality and Nonparametric Tests of Convexity, Journal of Economics, 81 (2), 155-192.

Brunello G., Comi S., Lucifora C. (1999), The Returns to Education in Italy: A New Look at the Evidence, Fondazione Eni Enrico Mattei, Milan, Nota di Lavoro, n. 101.99.

Canning, D., Fay, M., Perotti, R., (1994), Infrastructure and Growth, in Baldassarri, M., Paganetto, L., Phelps, E.S., (eds.) International differences in growth rates: Market globalization and economic areas. Central Issues in Contemporary Economic Theory and Policy series; London: Macmillan Press.

Cavanagh G.L., Elliott G., Stock J.H. (1995), Inference in models with nearly integrated regressors, Econometric Theory, 11, 1131-1147.

Chatterjee, S., Sakoulis, G., Turnovsky, S.J., (2003), Unilateral Capital Transfers, Public Investment, and Economic Growth, European Economic Review, 47(6): 1077-1103.

D’Acunto S., Destefanis S., Musella, M. (2004), Exports, Supply Constraints and Growth: An Investigation using Regional Data, International Review of Applied Economics, 18 (2), 167-188.

De la Fuente A. (2002), The Effect of Structural Fund Spending on the Spanish Regions: An Assessment of the 1994-99 Objective 1 CSF, CEPR DP n. 3673.

Deprins D., Simar L., Tulkens H. (1984), Measuring labor-efficiency in post offices, in Marchand M., Pestieau P., Tulkens H. (eds.), The performance of public enterprises: concepts and measurement, North Holland, Amsterdam.

Destefanis S., Storti G. (2002), Measuring Cross-country Technological Catch-up through Variable-parameter FDH, Statistical Methods and Applications, 11, 109-125.

Destefanis S., Taddeo A., Tornatore M. (2004), The stock of human capital in the Italian regions, WP 3.142, DISES, University of Salerno, (downloadable at 
http://www.dise.unisa.it/docenti/destefanis.htm).

Eisner, R. (1991), Infrastructure and Regional Economic Performance: Comment, New England Economic Review, 47-58.

Evans P., Karras G. (1994), Are Government Activities Productive? Evidence from a Panel of US States, Review of Economics and Statistics, 76 (1), 1-11.

Everaert G., Heylen F. (2001), Public Capital and Productivity Growth: Evidence for Belgium, 1953-1996, Economic Modelling, 18 (1), 97-116.

Faini, R., Galli, G., Giannini, C., (1993), Finance and Development: The Case of Southern Italy, in Giovannini, A., Finance and development: issues and experience, Cambridge, Cambridge University Press.

Farrell, M.J., (1957), The Measurement of Productive Efficiency, Journal of the Royal Statistical Society, series A 120 (3), 253-290.

Fisher, W. H. , Turnosvky, S.J. (1998), Public investment, Congestion and Private Capital Accumulation, The Economic Journal, 108, 399-413.

Garcia-Milà T., McGuire T.J., Porter R.H. (1996), The Effects of Public Capital in StateLevel Production Function Reconsidered, Regional Science and Urban Economics, 22, 229-241.

Glomm, G., Ravikumar, B. (1994), Public Investment in Infrastructure in a Simple Growth Model, Journal of Economic Dynamics and Control, 18, 1173-87.

Golden M.A, Picci L. (2004), Proposal for a New Measure of Corruption, Illustrated Italian Data, mimeo, UCLA, downloadable at http://golden.polisci.ucla.edu.

Gouyette C., Perelman S. (1997), Productivity Convergence in OECD Service Industries, Structural Change and Economic Dynamics, 8 (3), 279-295.

Gramlich, E.M. (1994), Infrastructure Investment: A Review Essay, Journal of Economic Literature, 32, 1176-1196.

Granger C.W.J., Lin J.L. (1995), Causality in the long run, Econometric Theory, 11, 530- 
536.

Gumbau-Albert M. (2000), Efficiency and Technical Progress: Sources of Convergence in the Spanish Regions, Applied Economics, 32 (4), 467-478.

Hall B.H., Mairesse J. (2002), Testing for Unit Roots in Panel Data: An Exploration Using Real and Simulated Data, mimeo, University of California at Berkeley, (downloadable at http://emlab.berkeley.edu/users/bhhall/papers/HallMairesseJan03\%20unitroot.pdf).

Hall R.E., Jones C.I. (1999), Why do some countries produce so much more output per worker than others?, Quarterly Journal of Economics, 114, 83-116.

Helliwell J., Putnam R. (1995), Economic Growth and Social Capital in Italy, Eastern Economic Journal, 21 (3), 295-307.

Henderson D.J, Russell R.R. (2001), Human Capital and Convergence: A ProductionFrontier Approach, Departamento de Economia, Universidad de Oviedo, Efficiency Series WP n. 07/2001.

Holtz-Eakin D. (1994), Public Sector Capital and the Productivity Puzzle, Review of Economics and Statistics, 76 (1), 12-21.

Im K.S., Pesaran M.H., Shin Y. (2003), Testing for unit roots in heterogeneous panels, Journal of Econometrics, 115, 53-74.

Karlsson S., Löthgren M. (2000), On the power and interpretation of panel unit root tests, Economics Letters, n. 66, 249-255.

Kerstens K., Vanden Eeckaut P. (1999), Estimating returns to scale using non-parametric deterministic technologies: a new method based on goodness-of-fit, European Journal of Operational Research, 113, 206-214.

Kittelsen S.A.C. (1999), Monte Carlo simulations of DEA efficiency measures and hypothesis tests, Memorandum n. 9, Department of Economics, University of Oslo.

Koopmans T.C. (1951), Analysis of Production as an Efficient Combination of Activities, 
in: Activity Analysis of Production and Allocation, Koopmans T.C. (ed.), Wiley, New York.

Kremers J.J.M., Ericsson N.E., Dolado J.J. (1992), The Power of Cointegration Tests, Oxford Bulletin of Economics and Statistics, 54 (3), 325-348.

Kumar S., Russell R.R. (2002), Technological Change, Technological Catch-Up, and Capital Deepening: Relative Contributions to Growth and Convergence, American Economic Review, 92, 527-548.

Lau S.H.M., Sin C.Y. (1997), Public Infrastructure and Economic Growth: Time Series Properties and Evidence, Economic Record, 73 (221), 125-135.

Lovell C.A.K. (1993), Production frontiers and productive efficiency, in: The Measurement of Productive Efficiency: Techniques and Applications, Fried H., Lovell C.A.K., Schmidt S. (eds.), Oxford University Press, London.

Lucas R. (1988), On the Mechanics of Economic Development, Journal of Monetary Economics, 22 (1), 3-42.

Lynde C., Richmond J. (1992), The Role of Public Capital in Production, Review of Economics and Statistics, 74 (1), 37-45.

Mankiw N.G., Romer D., Weil D.N. (1992), A Contribution to the Empirics of Economic Growth, Quarterly Journal of Economics, 107, 407-437.

Marrocu E., Paci R., Pala R. (2000), Estimation of total factor productivity for regions and sectors in Italy. A panel cointegration approach, RISEC, Rivista Internazionale di Scienze Economiche e Commerciali, 48, 533-558.

Mas M., Maudos J., Perez F., Uriel, E. (1996), Infrastructure and Productivity in the Spanish Regions, Regional Studies, 30(7), 641-49.

Maudos J., Pastor J.M., Serrano L. (2000), Convergence in OECD Countries: Technical Change, Efficiency and Productivity, Applied Economics, 32 (6), 757-765.

Ministero dell’Economia (2001), “Quarto Rapporto del Dipartimento per le Politiche dello 
Sviluppo 2000-2001”, Rome.

Morrison C.J., Schwartz A.E. (1996), State Infrastructure and Productive Performance, American Economic Review, 86, 1095-1111.

Mundlak Y. (2000), Agriculture and Growth: Theory and Measurement, Harvard University Press, Cambridge, Mass. .

Mundlak Y., Larson D.F., Butzer R. (1999) Rethinking Within and Between Regressions: The Case of Agricultural Production Functions, Annales d'Economie et de Statistique, n. 55-56, 475-501.

Munnell A. (1990), How Does Public Infrastructure Affect Regional Economic Performance?, in Munnell, A. (ed.), Is There a Shortfall in Public Capital Investment?, Boston MA, Federal Reserve Bank of Boston.

Munnell. A. H. (1992), Infrastructure Investment and Economic Growth, Journal of Economic Perspectives, 6(4), 189-198.

Paci R., Pusceddu N. (2000) Stima dello stock di capitale nelle regioni italiane, Rassegna Economica, Quaderni di Ricerca, 97-118.

Paci R., Saba A. (1998), The empirics of regional economic growth in Italy. 1951-1993, International Review of Economics and Business, 45, 515-542.

Paci R., Pigliaru F., Pugno M. (2003) Disparities in Economic Growth and Unemployment among the European Regions: a Sectoral Perspective, in B. Fingleton, A. Eraydin, R. Paci (eds.) Regional Economic Growth, SMEs and the Wider Europe, Aldershot: Ashgate, 75-102.

Pedroni P. (1997), Panel cointegration, asymptotic and finite sample properties of pooled time series tests, with application to the PPP hypothesis: new results, working paper, Indiana University.

Pedroni P. (1999), Critical values for cointegration tests in heterogeneous panels with multiple regressors, Oxford Bulletin of Economics and Statistics, 61, 653-670. 
Pereira, A.M. (2000), Is All Public Capital Created Equal?, Review of Economics and Statistics, 82(3), 513-18.

Pereira, A.M., Flores de Frutos, R. (1999), Public Capital Accumulation and Private Sector Performance, Journal of Urban Economics, 46, 300-322.

Picci L. (1999), Productivity and infrastructure in the Italian regions, Giornale degli Economisti e Annali di Economia, 58, 329-353.

Putnam R.D. (1993), Making Democracy Work. Civic traditions in modern Italy, Princeton University Press, Princeton, NJ.

Simar L., Wilson P. (2000a), Statistical Inference in Nonparametric Frontier Models: The State of the Art, Journal of Productivity Analysis, 13, 49-78.

Simar L., Wilson P. (2000b), A General Methodology for Bootstrapping in Non-Parametric Frontier Models, Journal of Applied Statistics, 27 (6), 779-802.

Simar L., Wilson P. (2001), Testing Restrictions in Non-Parametric Efficiency Models, Communications in Statistics: Simulation \& Computation, 30 (1), 159-184.

Sturm J.E. (1998), Public capital Expenditure in OECD Countries, Edward Elgar, Cheltenham.

Sturm J.E., de Haan, J. (1995), Is Public Expenditure Really Productive? New Evidence for the US and the Netherlands, Economic Modelling, 12(1), 60-72.

Sturm, J.E., Jacobs, J., Groot, P. (1995), Productivity Impacts of Infrastructure Investment in the Netherlands 1853-1913, SOM Research Report.

Tatom J.A. (1991), Public Capital and Private Sector Performance, Federal Reserve Bank of St. Louis Review, 73 (3), 3-15.

Tondl G. (1999), What determined the uneven growth of Europe's Southern regions? An empirical study with panel data, WP n. 30, Research Institute for European Affairs, Vienna.

Tulkens H. (1993), On FDH efficiency analysis: some methodological issues and 
applications to retail banking, courts and urban transit, Journal of Productivity Analysis, 4, 183-210.

Urbain J.P. (1992), On Weak Exogeneity in Error Correction Models, Oxford Bulletin of Economics and Statistics, 54, 187-207.

Vanhoudt P., Mathä T., Smid B. (2000), How productive are capital investments in Europe?, EIB Papers, 5, 81-106. 


\section{APPENDIX}

\section{TABLE 4.1 - Panel Unit Root Tests}

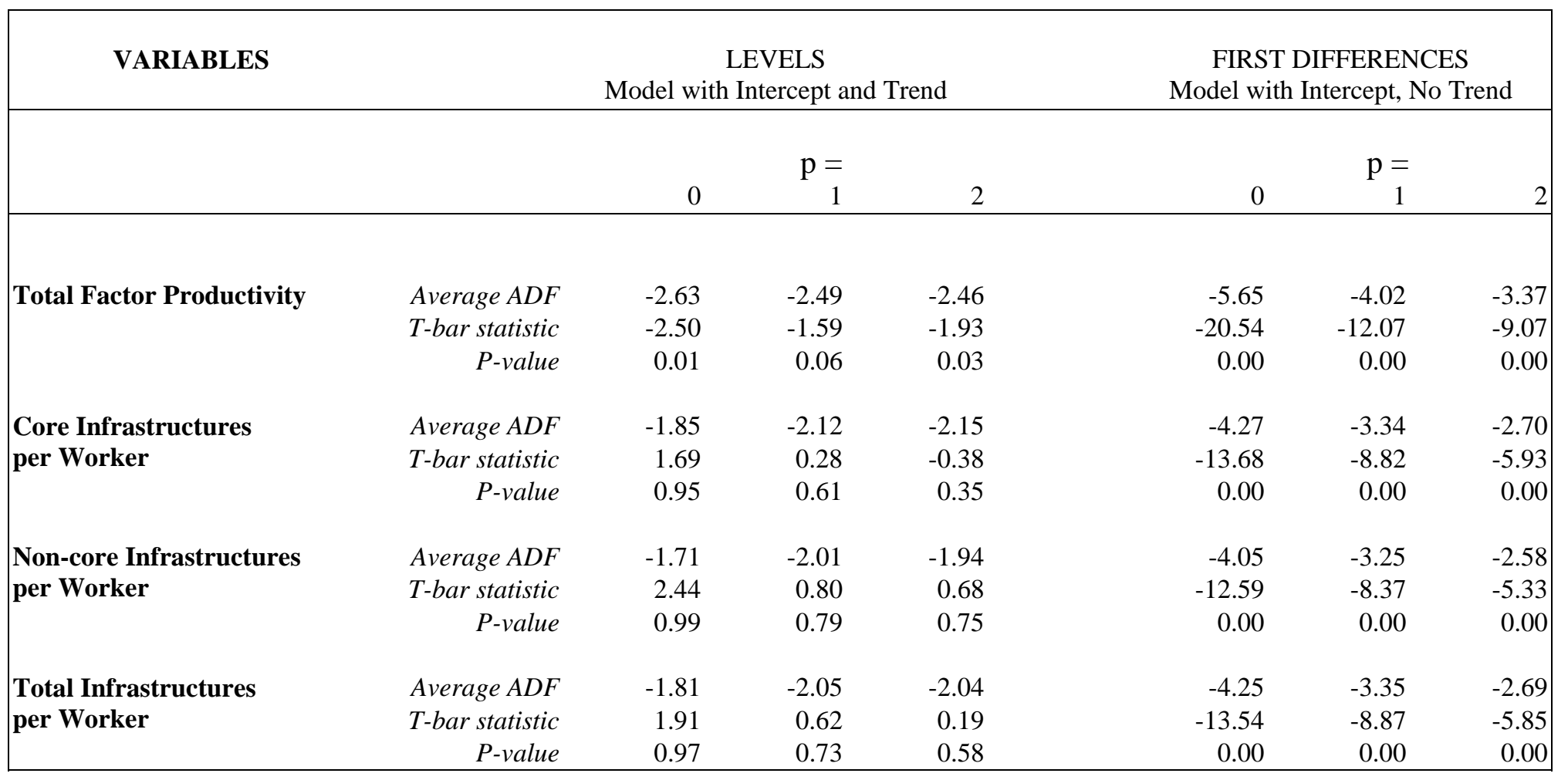

NB: Average ADF is the mean over the 20 regions of coefficients $\beta$ in the following ADF level- and first difference-regressions estimated region by region:

$$
\Delta \mathrm{y}_{\mathrm{t}}=\alpha+\delta \mathrm{t}+\beta \mathrm{y}_{\mathrm{t}-1}+\sum_{\mathrm{j}=1}^{\mathrm{p}} \Delta \mathrm{y}_{\mathrm{t}-\mathrm{j}}+\mathrm{e}_{\mathrm{t}} \quad \Delta \Delta \mathrm{y}_{\mathrm{t}}=\alpha+\beta \Delta \mathrm{y}_{\mathrm{t}-1}+\sum_{\mathrm{j}=1}^{\mathrm{p}} \Delta \Delta \mathrm{y}_{\mathrm{t}-\mathrm{j}}+\mathrm{e}_{\mathrm{t}}
$$

The test is carried out after removing from each variable the year-specific means. The P-values refer to the T-bar statistics, which are constructed from the average ADF's using the small sample adjustment from Im et al. (2002, Table 3). The T-bar statistics are distributed as N $(0,1)$ under the null hypothesis of non-stationarity. 
TABLE 4.2 - Long-run Coefficients

\begin{tabular}{|c|c|c|c|}
\hline REGIONS & $\begin{array}{l}\text { Total Factor Productivity and } \\
\text { Core Infrastructures per Worker }\end{array}$ & $\begin{array}{c}\text { Total Factor Productivity and } \\
\text { Non-core Infrastructures per Worker }\end{array}$ & $\begin{array}{l}\text { Total Factor Productivity and } \\
\text { Total Infrastructures per Worker }\end{array}$ \\
\hline Piemonte & 0.13 & 0.06 & 0.10 \\
\hline Valle d'Aosta & 0.01 & -0.04 & -0.01 \\
\hline Lombardia & 0.19 & 0.09 & 0.14 \\
\hline Trentino Alto Adige & 0.05 & -0.01 & 0.02 \\
\hline Veneto & 0.38 & 0.20 & 0.30 \\
\hline Friuli Venezia Giulia & 0.23 & 0.14 & 0.19 \\
\hline Liguria & 0.25 & 0.14 & 0.21 \\
\hline Emilia Romagna & 0.16 & 0.05 & 0.11 \\
\hline Toscana & 0.13 & 0.02 & 0.08 \\
\hline Umbria & 0.10 & -0.01 & 0.05 \\
\hline Marche & 0.08 & -0.01 & 0.04 \\
\hline Lazio & 0.08 & -0.02 & 0.03 \\
\hline Abruzzo & 0.14 & 0.02 & 0.10 \\
\hline Molise & -0.02 & -0.12 & -0.07 \\
\hline Campania & 0.11 & 0.00 & 0.05 \\
\hline Puglia & 0.27 & 0.13 & 0.20 \\
\hline Basilicata & 0.62 & 0.50 & 0.56 \\
\hline Calabria & 0.02 & -0.08 & -0.02 \\
\hline Sicilia & 0.13 & 0.05 & 0.09 \\
\hline Sardegna & 0.36 & 0.22 & 0.29 \\
\hline Mean (N-WEST) & 0.14 & 0.06 & 0.11 \\
\hline Mean (N-EAST) & 0.20 & 0.10 & 0.16 \\
\hline Mean (CENTRE) & 0.10 & 0.00 & 0.05 \\
\hline Mean (S-WEST) & 0.15 & 0.05 & 0.11 \\
\hline Mean (S-EAST) & 0.25 & 0.13 & 0.20 \\
\hline
\end{tabular}

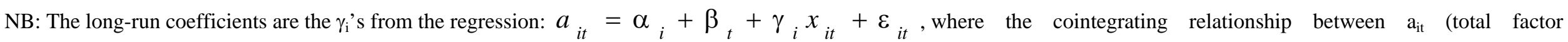
productivity) and $\mathrm{x}_{\mathrm{it}}$ (core, non-core, total infrastructures) can vary across regions. 


\section{TABLE 4.3 - Panel Cointegration Tests}

\begin{tabular}{|c|c|c|c|c|}
\hline MODELS & & & & \\
\hline & & 0 & $\mathrm{p}=$ & 2 \\
\hline Total Factor Productivity and & Average $A D F$ & -2.42 & -2.33 & -2.28 \\
\hline Core Infrastructures per Worker & $\begin{array}{r}\text { Test statistic } \\
P \text {-value }\end{array}$ & $\begin{array}{r}-2.14 \\
0.02\end{array}$ & $\begin{array}{r}-1.79 \\
0.04\end{array}$ & $\begin{array}{r}-1.52 \\
0.06\end{array}$ \\
\hline $\begin{array}{l}\text { Total Factor Productivity and Non-core } \\
\text { Infrastructures per Worker }\end{array}$ & $\begin{array}{r}\text { Average ADF } \\
\text { Test statistic } \\
P \text {-value }\end{array}$ & $\begin{array}{r}-2.40 \\
-2.04 \\
0.02\end{array}$ & $\begin{array}{r}-2.27 \\
-1.48 \\
0.07\end{array}$ & $\begin{array}{r}-2.26 \\
-1.40 \\
0.08\end{array}$ \\
\hline $\begin{array}{l}\text { Total Factor Productivity and Total } \\
\text { Infrastructures per Worker }\end{array}$ & $\begin{array}{r}\text { Average ADF } \\
\text { Test statistic } \\
P \text {-value }\end{array}$ & $\begin{array}{r}-2.41 \\
-2.11 \\
0.02 \\
\end{array}$ & $\begin{array}{r}-2.31 \\
-1.68 \\
0.05 \\
\end{array}$ & $\begin{array}{r}-2.28 \\
-1.52 \\
0.06 \\
\end{array}$ \\
\hline
\end{tabular}

NB: The first step of the cointegration test consists in estimating the regression: $a_{i t}=\alpha_{i}+\beta_{t}+\gamma_{i} x_{i t}+\varepsilon_{i t}$ which allows the long-run relationship between $\mathrm{a}_{\mathrm{it}}$ (total factor productivity) and $\mathrm{x}_{\mathrm{it}}$ (core, non-core, total infrastructures) to vary across regions.

Then, the average ADF's are obtained as means over the 20 regions of the $\beta$ coefficients in the following ADF regressions (estimated region by region):

$$
\Delta \varepsilon_{\mathrm{t}}=\alpha+\beta \varepsilon_{\mathrm{t}-1}+\sum_{\mathrm{j}=1}^{\mathrm{p}} \Delta \varepsilon_{\mathrm{t}-\mathrm{j}}+\mathrm{e}_{\mathrm{t}}
$$

The P-values refer to the ADF group-mean test statistics constructed from the average ADF's through the procedure suggested in Pedroni (1997, 1999). These statistics are distributed as $\mathrm{N}(0,1)$ under the null hypothesis of non-stationarity. 
TABLE 4.4 -Tests for the Presence of Long-run Effects

\begin{tabular}{|c|c|c|c|}
\hline MODEL & & $\begin{array}{c}\text { Null Hypothesis: } \\
\text { No Long-run Effects from } \\
\text { Infrastructures to } \\
\text { Total Factor Productivity }\end{array}$ & $\begin{array}{c}\text { Null Hypothesis: } \\
\text { No Long-run Effects from } \\
\text { Total Factor Productivity to } \\
\text { Infrastructures }\end{array}$ \\
\hline $\begin{array}{l}\text { Total Factor Productivity and } \\
\text { Core Infrastructures per Worker }\end{array}$ & $\begin{array}{r}\text { Likelihood Ratio Test } \\
\text { P-value }\end{array}$ & $\begin{array}{r}148.56 \\
0.00\end{array}$ & $\begin{array}{r}18.24 \\
0.57\end{array}$ \\
\hline $\begin{array}{l}\text { Total Factor Productivity and } \\
\text { Non-core Infrastructures per Worker }\end{array}$ & $\begin{array}{r}\text { Likelihood Ratio Test } \\
\text { P-value }\end{array}$ & $\begin{array}{r}134.71 \\
0.00\end{array}$ & $\begin{array}{r}29.77 \\
0.07\end{array}$ \\
\hline $\begin{array}{l}\text { Total Factor Productivity and } \\
\text { Total Infrastructures per Worker }\end{array}$ & $\begin{array}{r}\text { Likelihood Ratio Test } \\
\text { P-value }\end{array}$ & $\begin{array}{r}143.55 \\
0.00\end{array}$ & $\begin{array}{r}24.26 \\
0.23\end{array}$ \\
\hline
\end{tabular}

NB: The likelihood ratio tests (distributed as a $\chi^{2}$ with 20 degrees of freedom) refer to the following VAR system:

$\Delta \mathrm{a}_{\text {it }}=\alpha_{1 \mathrm{i}}+\alpha_{11 \mathrm{i}} \Delta \mathrm{a}_{\text {it }-1}+\alpha_{12 \mathrm{i}} \Delta \mathrm{x}_{\text {it }-1}+\alpha_{13 \mathrm{i}} \varepsilon_{\text {it }-1}+\mathrm{e}_{\text {it }}$

$\Delta \mathrm{x}_{\text {it }}=\alpha_{2 \mathrm{i}}+\alpha_{21 \mathrm{i}} \Delta \mathrm{a}_{\text {it }-1}+\alpha_{22 \mathrm{i}} \Delta \mathrm{x}_{\text {it }-1}+\alpha_{23 \mathrm{i}} \varepsilon_{\text {it }-1}+\mathrm{e}_{\text {it }}$

where $\mathrm{a}_{\mathrm{it}}$ is total factor productivity, $\mathrm{x}_{\mathrm{it}}$ are (core, non-core, total) infrastructures, and the $\varepsilon_{\mathrm{it}}$ 's are the residuals from the cointegrating regressions considered in Tables 4.2 and 4.3 . In the first column of the present table, the null hypothesis is that the $\alpha_{13 \mathrm{i}}$ 's are jointly equal to zero, while in the second column the null is that the $\alpha_{23 \mathrm{i}}$ 's are jointly equal to zero. 
TABLE 4.5 -FDH-VP Efficiency Scores: Regional Means over the Four Periods

\begin{tabular}{|c|c|c|c|c|}
\hline$\underline{\text { REGIONS }}$ & $\begin{array}{c}\text { Baseline } \\
\text { Model }\end{array}$ & $\begin{array}{c}+ \text { Core } \\
\text { Infrastructures }\end{array}$ & $\begin{array}{c}+ \text { Non-Core } \\
\text { Infrastructures }\end{array}$ & $\begin{array}{c}+ \text { Total } \\
\text { Infrastructures }\end{array}$ \\
\hline Piemonte & 0.96 & 0.99 & 0.99 & 0.99 \\
\hline Valle d'Aosta & 0.97 & 0.99 & 1.00 & 0.99 \\
\hline Lombardia & 0.98 & 1.00 & 0.99 & 1.00 \\
\hline Trentino Alto Adige & 0.99 & 0.99 & 0.99 & 0.99 \\
\hline Veneto & 0.94 & 0.99 & 0.99 & 1.00 \\
\hline Friuli Venezia Giulia & 0.88 & 0.98 & 0.97 & 0.97 \\
\hline Liguria & 0.79 & 0.83 & 0.86 & 0.84 \\
\hline Emilia Romagna & 0.97 & 0.99 & 0.98 & 0.98 \\
\hline Toscana & 0.97 & 1.00 & 1.00 & 1.00 \\
\hline Umbria & 0.95 & 1.00 & 1.00 & 1.00 \\
\hline Marche & 1.00 & 1.00 & 1.00 & 1.00 \\
\hline Lazio & 0.98 & 0.99 & 0.99 & 0.99 \\
\hline Abruzzo & 0.92 & 0.95 & 0.95 & 0.95 \\
\hline Molise & 0.91 & 0.96 & 0.91 & 0.95 \\
\hline Campania & 0.85 & 0.88 & 0.87 & 0.88 \\
\hline Puglia & 0.70 & 0.81 & 0.72 & 0.74 \\
\hline Basilicata & 0.76 & 0.77 & 0.76 & 0.76 \\
\hline Calabria & 0.73 & 0.73 & 0.73 & 0.73 \\
\hline Sicilia & 0.82 & 0.85 & 0.82 & 0.84 \\
\hline Sardegna & 0.87 & 0.93 & 0.87 & 0.90 \\
\hline Mean $(N-W E S T)$ & 0.93 & 0.95 & 0.96 & 0.96 \\
\hline Mean (N-EAST) & 0.95 & 0.99 & 0.98 & 0.98 \\
\hline Mean (CENTRE) & 0.97 & 1.00 & 1.00 & 1.00 \\
\hline Mean (S-WEST) & 0.82 & 0.85 & 0.82 & 0.84 \\
\hline Mean (S-EAST) & 0.82 & 0.87 & 0.83 & 0.85 \\
\hline
\end{tabular}


TABLE 4.6 - Descriptive Statistics and Tests on the FDH-VP Efficiency Scores

\begin{tabular}{|c|c|c|c|c|c|c|c|c|}
\hline \multirow{2}{*}{$\begin{array}{l}\text { PERIOD } \\
1970-75\end{array}$} & \multicolumn{2}{|c|}{$\begin{array}{l}\text { BASELINE } \\
\text { MODEL }\end{array}$} & \multicolumn{2}{|c|}{$\begin{array}{c}\text { BASELINE } \\
\text { MODEL } \\
\text { + CORE } \\
\text { INFRASTRUCTURES }\end{array}$} & \multicolumn{2}{|c|}{$\begin{array}{c}\text { BASELINE } \\
\text { MODEL } \\
+ \text { NON-CORE } \\
\text { INFRASTRUCTURES }\end{array}$} & \multicolumn{2}{|c|}{$\begin{array}{c}\text { BASELINE } \\
\text { MODEL } \\
\text { + TOTAL } \\
\text { INFRASTRUCTURES }\end{array}$} \\
\hline & $\begin{array}{l}\text { mean } \\
\text { std err. }\end{array}$ & $\begin{array}{l}0.87 \\
0.12\end{array}$ & $\begin{array}{r}\text { mean } \\
\text { std err. } \\
\text { T-test } \\
\text { KS-test }\end{array}$ & $\begin{array}{r}0.92 \\
0.11 \\
0.0013 \\
0.0035\end{array}$ & $\begin{array}{r}\text { mean } \\
\text { std err. } \\
\text { T-test } \\
\text { KS-test }\end{array}$ & $\begin{array}{r}0.91 \\
0.11 \\
0.0035 \\
0.0080\end{array}$ & $\begin{array}{r}\text { mean } \\
\text { std err. } \\
\text { T-test } \\
\text { KS-test }\end{array}$ & $\begin{array}{r}0.91 \\
0.11 \\
0.0026 \\
0.0035\end{array}$ \\
\hline 1976-81 & $\begin{array}{l}\text { mean } \\
\text { std err. }\end{array}$ & $\begin{array}{l}0.89 \\
0.11\end{array}$ & $\begin{array}{r}\text { mean } \\
\text { std err. } \\
\text { T-test } \\
\text { KS-test }\end{array}$ & $\begin{array}{r}0.92 \\
0.11 \\
0.0139 \\
0.0000\end{array}$ & $\begin{array}{r}\text { mean } \\
\text { std err. } \\
\text { T-test } \\
\text { KS-test }\end{array}$ & $\begin{array}{r}0.92 \\
0.11 \\
0.0266 \\
0.0035\end{array}$ & $\begin{array}{r}\text { mean } \\
\text { std err. } \\
\text { T-test } \\
\text { KS-test }\end{array}$ & $\begin{array}{r}0.92 \\
0.11 \\
0.0169 \\
0.0015\end{array}$ \\
\hline $1982-90$ & $\begin{array}{l}\text { mean } \\
\text { std err. }\end{array}$ & $\begin{array}{l}0.90 \\
0.11\end{array}$ & $\begin{array}{r}\text { mean } \\
\text { std err. } \\
\text { T-test } \\
\text { KS-test }\end{array}$ & $\begin{array}{r}0.93 \\
0.10 \\
0.0010 \\
0.0000\end{array}$ & $\begin{array}{r}\text { mean } \\
\text { std err. } \\
\text { T-test } \\
\text { KS-test }\end{array}$ & $\begin{array}{r}0.91 \\
0.12 \\
0.0733 \\
0.0010\end{array}$ & $\begin{array}{r}\text { mean } \\
\text { std err. } \\
\text { T-test } \\
\text { KS-test }\end{array}$ & $\begin{array}{r}0.92 \\
0.12 \\
0.0571 \\
0.0000\end{array}$ \\
\hline 1991-98 & $\begin{array}{l}\text { mean } \\
\text { std err. }\end{array}$ & $\begin{array}{l}0.90 \\
0.10\end{array}$ & $\begin{array}{r}\text { mean } \\
\text { std err. } \\
\text { T-test } \\
\text { KS-test }\end{array}$ & $\begin{array}{r}0.95 \\
0.08 \\
0.0000 \\
0.0000\end{array}$ & $\begin{array}{r}\text { mean } \\
\text { std err. } \\
\text { T-test } \\
\text { KS-test }\end{array}$ & $\begin{array}{r}0.93 \\
0.10 \\
0.0028 \\
0.0000\end{array}$ & $\begin{array}{r}\text { mean } \\
\text { std err. } \\
\text { T-test } \\
\text { KS-test }\end{array}$ & $\begin{array}{r}0.95 \\
0.09 \\
0.0000 \\
0.0010\end{array}$ \\
\hline $\begin{array}{l}\text { Mean is th } \\
\text { Std err. is } \\
\text { T-test is th } \\
\text { KS-test is }\end{array}$ & $\begin{array}{l}\text { riod me } \\
\text { period st } \\
\text { value of } \\
\text { p-value }\end{array}$ & (one & $\begin{array}{l}\text { cy scores; } \\
\text { he efficier } \\
\Gamma \text {-test con } \\
\text { v-Smirno }\end{array}$ & $\begin{array}{l}\text { cores; } \\
\text { ed vis-à } \\
\text { st comp }\end{array}$ & $\begin{array}{l}\text { baseline } \\
\text {-à-vis th }\end{array}$ & el; & & \\
\hline
\end{tabular}

